\title{
War on Heaven and Earth : Misotheistic Themes in Popular Culture
}

\section{Vainio, Olli-Pekka}

2019

Vainio , O-P 2019 , ' War on Heaven and Earth : Misotheistic Themes in Popular Culture ' , Dialog , vol. 58 , pp. 301-306 . https://doi.org/10.1111/dial.12520

http://hdl.handle.net/10138/334388

https://doi.org/10.1111/dial.12520

acceptedVersion

Downloaded from Helda, University of Helsinki institutional repository.

This is an electronic reprint of the original article.

This reprint may differ from the original in pagination and typographic detail.

Please cite the original version. 


\section{War on Heaven and Earth: Misotheistic Themes in Popular Culture}

Popular culture, or pop culture, is generally taken to be something that expresses the preferences of the masses. ${ }^{1}$ The etymological roots of the term are in the middle of the 19th century when it had openly a pejorative tone: popular culture represents something uncivilized; things that simple, lowbrow and uneducated people amuse themselves with. Correspondingly, high culture embodies noble interests of social elite and the dominant class.

The contemporary meaning of the term emerges in the 1960's when music and movie industries together with increased leisure time begin to have wide-ranging societal effects. The close link with commercialism gives rise to the idea of superficiality and the lack of seriousness. Yet pop culture can be, and has been, critical towards powers that be. ${ }^{2}$

In sociology, pop culture is seen as a mirror of society, but also as a force that transforms culture. For this reason, some popular forms of culture have often been opposed and vehemently criticized. From the 60 's onwards, the representatives of high culture or conservative establishment have criticized different manifestations of pop culture from Elvis's hypnotic hip movements to Harry Potter's satanic rites. The newer phenomenon has been criticism by illiberal left, who have called out once progressive TV shows such as Friends and Sex and the City for being regressive and not "woke" enough. ${ }^{3}$

In pop culture studies there are two focus areas. The first analyzes how culture and its basic themes are described and treated in pop culture, and the second assesses the critical function of pop culture, that is, how it challenges existing beliefs, taboos, institutions, and other structures. In this essay, I will employ both of these approaches.

\section{God in pop culture}

\footnotetext{
${ }^{1}$ Lynn Scofield Clark and Seth Walker, "Popular Culture and Religion in America," Oxford Encyclopedia of Religion in America (Oxford University Press, 2018).

2 Sometimes so-called alternative- or underground cultures are treated as a part of popular culture even though they try not to be popular. For example, punk was once a form of culture that resisted the mainstream but recently punk has become mainstream itself. I heard someone once say that today it is punk to wear a tie, have a job and listen to Jordan Peterson's lectures. Pop culture is also a quite vague concept and it is hard to draw a line between pop and high culture. For long, movies were thought to belong to pop culture but in which category should one put, for example, Terrence Malick's Knight of Cups? Or the movies by Aronofsky and Bergman, or the lyrics of Bob Dylan?

${ }^{3}$ An example from Finnish mainstream media where a columnist ranks tv-series based on their wokeness is Ina Mikkola, "Ina Mikkolan Kolumni: Sinkkuelämää Täytti 20 Vuotta - ‘Ajasta Jälkeen Jäänyt Sarja on Elitistinen Ja Stereotyyppinen,”’ YLE, 2018, https://yle.fi/uutiset/3-10323484.
} 
It seems that religion and God have always been a natural part of the pop culture. Also, the ways in which religion has appeared in popular culture have always been quite the same. For the sake of brevity, I will not focus on messiah figures and other biblical or religious elements in pop culture since these themes are certainly familiar to many already. The same applies to films and television series depicting the lives of the priests (like Father Camillo, Father Brown, Rev., Broken, Calvary, First Reformed, etc.). Nor do I evaluate the religious elements of pop or metal music as there exist already a good amount of studies on the topic. ${ }^{4}$

Instead, I evaluate particular critical narratives of religion in pop culture. I note briefly some early cases where criticism is primarily directed at religious abuses. Next, I make some observations about the misotheistic tradition in which the relationship between religious reality and human life is more complicated. Finally, I make some remarks on the use of religious and quasireligious elements in the pop culture and what kind of effects they might have on our social imagination.

\section{The critique of the Catholic church in the Renaissance literature}

If pop culture as a concept is understood as a critique or commentary of high culture that was understandable even among non-educated people, its history is naturally long. Here I, however, wish to start from anarco-humorous works of Francois Rabelais (1483-1553), in which he depicts the adventures of two giants, Gargantua and Pantagruel. ${ }^{5}$

Rabelais, a doctor and member of Benedictine order, appreciated greatly Erasmus of Rotterdam, who, In Praise of Folly (1511), had criticized the popular religiosity of his time, which adhered to outward habit but forgot the inner life. The central criticism focused on hypocrisy, which Erasmus thought poisoned the piety of the Church. Obviously, there were many factors in the reform program of Erasmus, which the Lutheran reformation later adopted.

Although Rabelais's criticism is in many ways stylistically similar to Erasmus, it goes a long way further. The Catholic establishment is often vehemently ridiculed. In one adventure, Pantagruel's party ends up in the island of Papimani, which is inhabited by over-enthusiastic Catholic Christians who love above all the papal decrees and canons to which they sing praises. This was a thinly-veiled parody of the Council of Trent.

\footnotetext{
${ }^{4}$ E.g., Marcus Moberg, Faster for the Master!: Exploring Issues of Religious Expression and Alternative Christian Identity within the Finnish Christian Metal Music Scene (Åbo: Åbo Akademi University Press, 2009).

${ }^{5}$ Franç,ois Rabelais, Gargantua and Pantagruel (London: Penguin, 2006).
} 
A comic relief character in Pantagruel's party is a monk, Brother John. In one adventure, John sets up his own monastery, which has no walls and whose inhabitants can marry and live as they like. John is also a gluttonous and violent alcoholic who fantasizes, for example, about ravaging virgins. ${ }^{6}$ Rabelais's idea of better repentance seems to require that, instead of hypocrisy, the bad deeds should be practiced openly and authentically without the idea that an outside authority should control the lives of individuals. John, however, occasionally represents common sense and discretion, although his journey is often in many ways less than ideal.

Slightly similar criticisms occur in Alexander Dumas's Three Musketeers (1844). The Musketeers are faithful, although imperfect, members of the Catholic Church. They wage a war against the Hugenots and Aramis eventually becomes the leader of the Jesuits. The notorious cardinal Richelieu is not the true villain of the story, though he is not a saint either. The church men and women are not evil because they are representatives of the Christian faith, but because they, in the matter of fact, are not; their crime is that they have abandoned their ideals.

\section{Misotheism and anantroposentrism}

Misotheism simply means "the hate of god": God or gods are thought to exist (in some sense), but instead of worship, they are subjected to indifference or hatred. God or gods can also be described as indifferent or even cruel towards people. ${ }^{7}$

For example, Mary Shelley's Frankenstein (1818) can be interpreted as a misotheistic novel. Viktor Frankenstein, a scientist shaken by the inevitability of death, creates a new Adam, a monster out of parts of dead people, which he does not love. Thus, the novel depicts, by means of fiction, what it is to live alone thrown into the world, and hated and shunned by one's creator. The novel also plays with the roles of God and Satan: who is ultimately evil and who is good? Eventually, the real monster is Viktor, a false god who avoids the responsibility for his creation. ${ }^{8}$

6 Leonard Ares, "Rabelais' Brother John: Humor and Humanism," The Montreal Review July (2013), http:/ /www.themontrealreview.com/2009/Rabelais-Brother-John-Humor-and-Humanism.php..

${ }^{7}$ On misotheism in literature, see Bernard Schweizer, Hating God. The Untold Story of Misotheism (Oxford: Oxford University Press, 2011).

8 The online version of Shelley's Frankenstein can be found from https://www.gutenberg.org/files/84/84-h/84-h.htm and the following quotes are from this source. Frankenstein to the Monster: "Cursed be the day, abhorred devil, in which you first saw light! Cursed (although I curse myself) be the hands that formed you! You have made me wretched beyond expression. You have left me no power to consider whether I am just to you or not. Begone! Relieve me from the sight of your detested form." Monster to Frankenstein: "Yet mine shall not be the submission of abject slavery. I will revenge my injuries; if I cannot inspire love, I will cause fear, and chiefly towards you my arch-enemy, because my creator, do I swear inextinguishable hatred. 
The master of cosmic Horror, H. P. Lovecraft, presents in his novels an alternative reality that is very much like ours. ${ }^{9}$ Lovecraft's cosmos is amoral and strictly naturalistic. His monsters are not exactly supernatural, but materialistic, although they transcend the categories of understanding. Even if the world view of Lovecraft is scientific, the reality always exceeds what we know about it, and it is science that drives people towards the better understanding of the nature of reality - which inevitable leads to madness. ${ }^{10}$ His short story Call of Chulthu begins with the statement:

The most merciful thing in the world, I think, is the inability of the human mind to correlate all its contents. We live on a placid island of ignorance in the midst of black seas of infinity, and it was not meant that we should voyage far. The sciences, each straining in its own direction, have hitherto harmed us little; but some day the piecing together of dissociated knowledge will open up such terrifying vistas of reality, and of our frightful position therein, that we shall either go mad from the revelation or flee from the deadly light into the peace and safety of a new dark age.

Lovecraft was known for his hatred of Christianity; when he heard about the persecution of the first Christians as a young boy, he said that he immediately rooted for the lions. ${ }^{11}$ The novels frequently introduce ministers from different denominations, but they usually disappear from the story very quickly. The god of Christians is a weak god who must move aside and make way to the more powerful Old Ones. ${ }^{12}$ The Old Ones are likened to the idols described in the Old Testament, which in Lovecraft's world are monsters residing in other dimensions. ${ }^{13}$

Have a care; I will work at your destruction, nor finish until I desolate your heart, so that you shall curse the hour of your birth." Frankenstein: "In a fit of enthusiastic madness I created a rational creature and was bound towards him to assure, as far as was in my power, his happiness and well-being. This was my duty..."

9 Timo Airaksinen, The Philosophy of H. P. Lovecraft: The Route to Horror (Bern: Peter Lang, 1999).

${ }^{10}$ Lovecrafts works can be accessed online in http://www.hplovecraft.com/writings/ All the following quotations are from this source.

11 Often Edgar Allan Poe is mentioned together with Lovecraft as one of the masters of gothic horror. Poe's relationships with religion was, however, much more positive although it altered throughout his life. His works include a hymn to Virgin Mary and his own magnum opus is religious and metaphysical speculation Eureka.

12 The same themes are treated in a recent Netflix movie The Apostle (2018).

${ }^{13}$ In a scene in The Shadow over Innsmouth an old drunkard explains the origins of marine deity Dagon: "Poor Matt-Matt he allus was agin' it — tried to line up the folks on his side, an' had long talks with the preachers—no use - they run the Congregational parson aout o' taown, an' the Methodist feller quit-never did see Resolved Babcock, the Baptist parson, 
Some cultures have retained remnants of the worship of the Old Ones; in these outwardly primitive cults, however, the reality is reached in bare and raw form. These cults live in the expectation of endtime, when the Old Ones return and humanity is released from its delusions and self-deception. In Call of Chulthu, this coming state of bliss is described thus:

That cult would never die till the stars came right again, and the secret priests would take great Cthulhu from His tomb to revive His subjects and resume His rule of earth. The time would be easy to know, for then mankind would have become as the Great Old Ones; free and wild and beyond good and evil, with laws and morals thrown aside and all men shouting and killing and revelling in joy. Then the liberated Old Ones would teach them new ways to shout and kill and revel and enjoy themselves, and all the earth would flame with a holocaust of ecstasy and freedom. Meanwhile the cult, by appropriate rites, must keep alive the memory of those ancient ways and shadow forth the prophecy of their return. ${ }^{14}$

Lovecraft's protagonists are often well-trained scientists who have to deal with issues they are unable to understand. This is a typical plot in Gothic horror stories where a person who is skeptical or has "scientific world view" meets strange things and are forced to change their minds. ${ }^{15}$ In contrast to the previous horror genre, in Lovecraft's stories the protagonists do not really achieve or learn anything. They will change their minds, for sure, but as a result many will lose their minds and kill themselves when they realize that cosmos is indifferent to people - and in fact very cruel. ${ }^{16}$ In science fiction of our own time, a similar vision has been offered by Chinese author Cixin Liu, whose most famous admirers include President Barack Obama. ${ }^{17}$ Liu writes so-called hard science

agin — Wrath o' Jehovy—I was a mighty little critter, but I heerd what I heerd an' seen what I seen—Dagon an' Ashtoreth— Belial an' Beëlzebub_Golden Caff an' the idols o' Canaan an' the Philistines—Babylonish abominations—Mene, mene, tekel, upharsin-".

${ }^{14}$ Lovecraft has been accused of racism because of his interest in eugenics, which is also said to manifest in his stories, for example in the uneasiness his characters feel towards mixing of our genetic heritage, and one-sided treatments of native cultures. See, e.g., his short story Arthur Jermyn. Nonetheless, primitive cultures are in his novels often those who possess greater and more true understanding of the cosmos than the one of bourgeois delusion, which avoids confronting the hard questions about life.

15 Zöe Lehmann Imfeld, The Victorian Ghost Story and Theology: From Le Fanu to James (London: Palgrave Macmillan, 2016).

16 A philosophical exploration of this theme is Guy Kahane, "Our Cosmic Insignificance," Nous 48, no. 4 (2014): 745-72.

${ }^{17}$ There is a blurp by Obama in the cover of Three Body Problem: "wildly imaginative, really interesting". In an interview, Obama said to like the book because it makes his own problems look petty. https://www.tor.com/2017/01/17/barack-obamabooks-the-three-body-problem/ 
fiction, where scientific and technological credibility is a key value. In addition to this, Liu also seeks sociological credibility, and especially his famous Three-Body Problem trilogy is a profound study of human nature and human relationship with cosmos.

Liu's parents were killed in the socialist Cultural Revolution, and possibly because of this, Liu's texts portray existentialist rage and steer towards pessimism. In Liu's novels, humanity is basically dumb and irrational. Irrationality is not, however, a product of the religions, which Liu describes quite sympathetically. Instead, the stupidity results from our delusional view of the cosmos and our place in it.

In the novel "The Devourer," Liu portrays debate between the Ambassador of the Devourer Empire, soon to arrive to destroy Earth, and a representative of the Earth, in which this human man calls on the ambassador's morality to not to destroy humankind. The Ambassador bluntly replies: "The cosmos has no place for morality." ${ }^{~} 18$ Eventually, the Earth is destroyed, but people are given the opportunity to connect themselves in a happiness machine that will allow them a happy life, which will end in them becoming food for the citizens of the Empire.

In Liu's world, religion can be a useful opium for the masses, but it is not worth criticizing or opposing, and for many it is a highly recommended option. Just as in Lovecraft's case, the deepest nature of reality is too heavy for us to bear. However, while Lovecraft represents pure misotheism, Liu's philosophy is merely anantroposentric. ${ }^{19}$ Human race is not the center of everything, and human life has no particular purpose or value. Yet Liu, unlike Lovecraft, thinks that we can nonetheless live and die with dignity. The paradigmatic religious-philosophical form of existence is a kind of stoic samurai who accepts his destiny and does his duty even if it does not make sense from the cosmic perspective. In misotheist imagination, it is always easier to believe in the existence of Satan rather than of God. This is the premise in HBO's Victorian horror series Penny Dreadfull, which centers on Catholic Christian Vanessa Ives, who has a special place in the heart of the Devil because of her clairvoyant gifts. Vanessa tries to keep herself and her faith alive (she often fails), because God is just silent and lets the evil prevail. In the series, the evil forces manifest in impressive ways and they seem almost invincible, while goodness is always hidden and weak, and until the last minute evil seems to win every match.

Mike Magnola's comic hero Hellboy inhabits a similar cosmos that lends much of its elements from Lovecraft, and also folk horror traditions around the globe. Hellboy is a little red horned demon, summoned to this world by an occultist Nazi cult, and raised by a good-natured American scientist as

\footnotetext{
${ }_{18}$ Cixin Liu, "The Devourer," in The Wandering Earth (London: Head of Zeus, 2013), 273-324., 290.

${ }^{19}$ For a profound account of anantropocentrism, see Tim Mulgan, Purpose in the Universe: The Moral and Metaphysical Case for Ananthropocentric Purposivism (Oxford: Oxford University Press, 2015).
} 
his own son. As an adult, Hellboy is part of a pack of mutants who fight against the forces of evil. Hellboy also has his own internal struggle: he was born a demon, but does his birth dictate his being? In the movie Hellboy (2004), he is tempted to embrace his origins and to become a demon who opens the interdimensional door for the Lovecraftian horrors enter and consume our world. In the climax of the movie, he squeezes a small cross, a gift from his father, in his hand, and breaks his horns. The last words of the movie state: "What makes a man a man? A friend of mine once wondered: Is it his origins? The way he comes to life? I don't think so. It's the choices he makes. Not how he starts things but how he decides to end them."

\section{Console religion}

When speaking about popular culture, we cannot forget the gaming industry, which is currently three times bigger in terms of money than the Hollywood film industry. A creative description of religion appears in the post-apocalyptic Horizon Zero Dawn (2017), which depicts mankind thousands of years after the collapse of the civilization initiated by rogue AI. Humanity has been reborn with the help of virus-free AI machines, and around these machines has emerged a primitive matriarchal cult. The religious elements are employed more profoundly than in your average game. ${ }^{20}$ In Horizon Zero Dawn, religion, particularly in the early stages of the game, plays an essential role in the choices of individuals and communities. Religion provides social cohesion and promotes survival, even though it also controls its members in potentially harmful ways.

As the game progresses, the role of religion loses its meaning in the life of characters and is replaced by the scientific explanation of events. Both the protectors and evil gods are revealed to be actually AI machines. Even though the theme is not underlined, the game retells the story of secularization: we move from childhood to adulthood and from religion towards science. ${ }^{21}$

The long-running Tomb Raider series has often depicted the myths and religious elements of ancient cultures. In the latest game The Shadow of Tomb Raider (2018), heroine Lara Croft accidentally launches a series of events leading to the end of the world as prophesied by the Mayan religion, with syncretistic twists. The visually most impressive episode of the game follows the events of Christ's crucifixion, and the main story also culminates in a scene similar to Isaac's sacrifice. The game assumes that the world beyond this world, about which the different religions talk about, is real, but ultimately dangerous, and

\footnotetext{
${ }^{20}$ Misotheistic themes can be found in the popular God of War series in which Zeus's son Kratos fights against other gods. This is not a particularly profound philosophical commentary since the games mainly reproduce the ancient myths of various traditions and use these as platform for smackdowns between gods.

${ }^{21}$ This story of growth is depicted, e.g., in Enlightenment philosophies of Comte, Kant and Dewey.
} 
people should stay away from it. At the end of the game, Lara redefines her mission: the great mysteries should not be solved, but they must be protected.

Religious symbolism has also been strongly presented in the popular FarCry series. The basic idea of the games is the following: the hero is isolated in the middle of a strange culture where he or she has to engage in guerrilla warfare against different opponents who oppress the local population. FarCry3 is located in a tropical archipelago near Thailand, where remains of Christian past are visible (there are abandoned churches and places with Christian names). Local people have rejected Christianity and adopted a primitive cult that celebrates sexuality and violence. FarCry4 is located in a country like Tibet with versions of Hindu and Buddhist cults. FarCry Primal takes place in the prehistory of mankind, in which primitive religions play a pivotal role.

The latest installation of the series, FarCry5, received exceptional attention before its launch as the venue was not an exotic island or other country, but Montana, where a familiar looking cult oppressed local population. The ads of the game were consciously controversial, and the game was expected to be a statement against the rise of Trump and the unhappy alliance of the religious right with white nationalism. ${ }^{22}$ The religion of the game, however, is a somewhat non-reflective combination of self-help mentoring, Mormonism, 60's newage with drugs and hippies, and evangelical Christianity that combines sadism, drug trafficking, and the apocalypse. That's like Dexter, Tony Robbins and Narcos combined with doomsday prepping.

The interplay of religion and politics is, however, deliberately ambiguous - perhaps for the economic reasons as you do not want to insult your base. But playing it too safe managed to make some people angry anyway. A critic of Forbes magazine was disappointed that the game was not political and antireligious enough. ${ }^{23}$ The rednecks and hill people of Montana are quite sympathetic, one of the heroes is a black Christian pastor, and worst of all, the cult has among its members different races and genders. So the players could not blow their post-Trump steam out by slaughtering redcap males en masse. In

22 One ad mixes Amazing grace with disturbing images of gun-wielded congregants:
https://www.youtube.com/watch?v=PiFm6Fo0oH8
23 Paul Tassi, “Far Cry 5' Is Apolitical To The Point Of Absurdity," Forbes, 2018,
https://www.forbes.com/sites/insertcoin/2018/03/27/far-cry-5-is-apolitical-to-the-point-of-absurdity/\#48dbf4ae5c2e.: "You might think that a religious cult in rural Montana might be forced to address issues of race or gender, but simply put, neither exist in the world of Far Cry. Women and men fight alongside one another on both sides of the conflict. Race is literally not mentioned once. Despite Eden's Gate and the Seed family giving off some extremely white supremacist vibes in their conceptualization and their iconography, they truly are colorblind. Both sides have white, black and Asian fighters, you, the lead character, can be any race you want and it has zero effect on the story whatsoever. Eden's Gate may want to kill you, but it's definitely not because you're not white. Truly, a forward-thinking murderous cult.” 
addition, as in FarCry games in general, the final twist is always an opportunity to join the ranks of the enemy.

\section{The End is Nigh?}

The critics of FarCry5 were concerned that the division between good and bad was not clear enough, that is, it does not manifest in visible and unambiguous way. Instead, the world of the game is complicated in this regard: just by looking at a person you cannot know whether he or she is good or bad - of course unless they are shooting at you.

The criticism resonates with the analysis of the popular culture, and especially recent films, offered by the New York Times columnist and author David Brooks. ${ }^{24}$ Brooks suggests that the great stories that people tell themselves to make sense of their lives can be divided into myths and parables. Knowing that the distinction is a sketchy one, he argues that the mythical interpretation of reality is typically pre- or non-Christian and the world of parables is typically Judeo-Christian. In mythical stories, the world is divided between good and evil, oppressors and oppressed, black and white, and regression and progression - and everyone is immediately aware of who is who. The myths are about primal battle against the forces of chaos and this $U r$-struggle forms the basis for the ontology of violence so that the simplest, most real and most beautiful thing in the world is always the holy war for the noble cause. The world of parables shares the same basic dualism, but the lines are not drawn between the hearts, not through each individual heart. ${ }^{25}$ The reality is influenced by the forces of goodness and evil, but the central problem is not how to deal with the current incarnation of evil. ${ }^{26}$ In the center of the story there is an individual who has to undergo an internal struggle: I, who thought to be the brave Marduk, might actually be Tiamat. Or to what extent who was thought to be Tiamat, is actually Marduk.

Brooks suggests (I think a bit hastily) that the world of popular culture is almost purely mythical. This is reflected, for example, in the most popular films of our time, that is, the Marvel-saga, where the parable

24 David Brooks, "The Fourth Great Awakening," New York Times, 2018, https://www.nytimes.com/2018/06/21/opinion/marvel-video-games-religion.html.

${ }^{25}$ Yes, I am paraprasing Solzenitzyn here: "If only it were all so simple! If only there were evil people somewhere insidiously committing evil deeds, and it were necessary only to separate them from the rest of us and destroy them. But the line dividing good and evil cuts through the heart of every human being. And who is willing to destroy a piece of his own heart?” Alexander I. Solzhenitsyn, The Gulag Archipelago (New York: Harper \& Row, 1973), 168.

${ }^{26}$ Storywise this tends make the plots boring and repetitive, which has been the problem with superhero movies and other blockbusters that rely on this same model: the evil tries to destroy the world (why this would make any sense in the first place is not typically explained) and heroes must kill or stop the evil. 
of perspective is almost nonexistent. ${ }^{27}$ Brooks does not consider this as harmless pastime, because pop culture influences the social imaginary of people and the mythical image of the world reinforces strong, simplistic and dualistic juxtapositions.

If the world of the Marvel movies is somewhat naive and black-and-white, a sort of counterforce is found from DC universe, in particular in Christopher Nolan's Batman trilogy. For Batman, the main problem is the difficulty of countering evil with violence. Everytime Batman fights evil, he risks becoming evil himself. This is the temptation Joker throws at Batman in Dark Knight: morality is purely contingent and based on false consciousness. ${ }^{28}$ Batman should come to realize this and become übermench like the Joker, who is, or tries very hard to be, beyond good and evil.

Despite the unintellectual aura, the descriptions of religion in popular culture enable often nuanced treatments of human existence. Even if it sometimes can be taken as a brainless form recreation, pop culture can influence our thinking. The parodies of abuses have long been known and their value is obvious. However, the misotheistic tradition transforms the nature of criticism in an interesting way. For example, Lovecraft and Liu's misotheism and anantroposentrism are relentless criticisms of all simplistic philosophies of life. Misotheism also urges one to ask difficult questions about good and evil, meaning and insignificance. Misotheism also makes it difficult or even impossible to accept simple descriptions of reality and also simplistic critiques of religion, and equally simplistic responses, which we have created in our own image.

\footnotetext{
27 There are some exceptions, like the 3rd season of Netflix's Daredevil (2018).

${ }^{28}$ In the famous interrogation scene, the Joker says: “To them, you're just a freak, like me! They need you right now, but when they don't, they'll cast you out, like a leper! You see, their morals, their code, it's a bad joke. Dropped at the first sign of trouble. They're only as good as the world allows them to be. I'll show you. When the chips are down, these... these civilized people, they'll eat each other. See, I'm not a monster. I'm just ahead of the curve.”
} 